\title{
Beneficial Effects of Moxonidine on Cerebral Vasospasm After Experimental Subarachnoid Hemorrhage
}

\author{
Deneysel Subaraknoid Kanamadan Sonra Serebral Vazospazm Üzerine \\ Moksonidin'in Faydalı Etkisi
}

\author{
Mustafa Kemal ILIK ${ }^{1}$, Yalcin KOCAOGULLAR ${ }^{2}$, Osman $\mathrm{KOC}^{3}$, Hasan ESEN ${ }^{4}$ \\ ${ }^{1}$ Mevlana University, Faculty of Medicine, Department of Neurosurgery, Konya, Turkey \\ ${ }^{2}$ Necmettin Erbakan University, Meram Faculty of Medicine, Department of Neurosurgery, Konya, Turkey \\ ${ }^{3}$ Necmettin Erbakan University, Meram Faculty of Medicine, Department of Radiology, Konya, Turkey \\ ${ }^{4}$ Necmettin Erbakan University, Meram Faculty of Medicine, Department of Pathology, Konya, Turkey
}

Corresponding Author: Mustafa Kemal ILIK / E-mail: mkilik@gmail.com

\section{ABSTRACT}

AIM: This study was designed to examine the efficacy of moxonidine, a centrally acting antihypertensive agent that is a selective ligand for 11-imidazoline sites, in a rabbit cerebral vasospasm model.

MATERIAL and METHODS: Twenty-four white, male New-Zealand rabbits weighing 2500-3200 gr. were randomly allocated into three groups as group $1=$ control group, group $2=$ subarachnoid hemorrhage $(\mathrm{SAH})$ alone group, and group $3=\mathrm{SAH}+$ moxonidine (treatment) group.

Cerebral angiography was performed to all rabbits before ( $D a y=0$, basal angiography) and 72 hours after the induction of SAH. Intraperitoneal moxonidine $(0.5 \mathrm{mg} / \mathrm{kg})$ treatment was started after the induction of SAH and continued once a day for 72 hours in the treatment group.

RESULTS: No statistically significant difference was determined in basal angiographic luminal diameter of the basilar artery between groups $(p>0.005)$. After $\mathrm{SAH}$, the follow-up angiographic basilar artery luminal diameter significantly changed in treatment group when compared with the SAH alone group $(p<0.001)$. The pathologically examined basilar artery luminal area was different between these groups $(p<0.005)$.

CONCLUSION: Moxonidine treatment as a centrally acting antihypertensive agent was found to be very beneficial in the treatment of vasospasm by increasing the angiographic diameter and the pathologic luminal area and reducing muscular wall thickness.

KEYWORDS: Subarachnoid hemorrhage, Cerebral vasospasm, Experimental, Moxonidine, Rabbit

öz

AMAÇ: Çalışma I1-imidazolin bölgeleri için selektif bir ligand olan merkezi etkili antihipertansif ajan moksonidinin bir tavşan serebral vazospazm modelinde etkinliğini incelemek üzere tasarlanmıştır.

YÖNTEM ve GEREÇLER: Yirmi dört beyaz, 2500-3200 gr. ağırlığında erkek, Yeni Zelanda tavşanı rasgele olarak üç gruba bölünmüştür grup $1=$ kontrol grubu, grup $2=$ sadece subaraknoid kanama (SAK) grubu ve grup $3=S A K+$ moksonidin (tedavi) grubu.

Tüm tavşanlarda SAK indüksiyonu öncesinde (Gün=0, bazal anjiyografi) ve 72 saat sonrasında serebral anjiyografi yapılmıştır. SAK indüksiyonundan sonra tedavi grubunda intraperitoneal moksonidin $(0,5 \mathrm{mg} / \mathrm{kg})$ tedavisi başlatılmış ve günde bir kez olmak üzere 72 saat devam ettirilmiştir.

BULGULAR: Gruplar arasında baziller arterin anjiyografik luminal çapı açısından istatistiksel olarak önemli bir fark bulunmamıştır ( $p>0,005)$. SAK sonrasında takip anjiyografik baziller arter luminal çapı sadece SAK grubu ile karşılaştırıldığında tedavi grubunda istatistiksel olarak anlamlı şekilde değişiklik göstermiştir $(p<0,001)$. Patolojik olarak incelenen baziller arter lümeni alanı bu iki grup arasında istatistiksel açıdan anlamlı fark göstermiştir $(\mathrm{p}<0,005)$.

SONUÇ: Merkezi etkili bir antihipertansif ajan olarak moksonidin tedavisi anjiyografik çapı ve patolojide lümen alanını artırıp müsküler duvar kalınlığını azaltarak vazospazm tedavisinde çok faydalı bulunmuştur.

ANAHTAR SÖZCÜKLER: Subaraknoid kanama, Serebral vazospazm, Deneysel, Moksonidin, Tavşan 


\section{INTRODUCTION}

The prolonged and reversible contraction of the cerebral arteries after aneurysmal subarachnoid hemerrhage (SAH) is referred to as cerebral vasospasm. Cerebral vasospasm is a major leading factor of morbidity and mortality in aneurysmal subarachnoid hemorrhage patients $(3,12)$. Current medical treatments fail to prevent vasospasm, and the exact pathogenesis of this disease remains incompletely understood (12).

Moxonidine, a centrally acting antihypertensive agent, is a selective ligand for 11 imidazoline sites (4). It inhibits catecholamine release and is therefore expected to exert an antiadrenergic effect at various levels in the regulation of the cardiovascular system. Moxonidine possesses pronounced diuretic/natriuretic effects and has beneficial effects on blood lipid levels, hyperinsulinemia, and glucose intolerance (20). It has recently been proposed that drugs acting on the imidazoline receptors (IRs) may also be neuroprotective (11).

Antihypertensive agents such as clonidine and aproclonidine have been shown to ameliorate experimental vasospasm (19), but moxonidine has some different features from these agents. Moxonidine has more selective agent from clonidine to Imidazoline I receptors (18). Moxonidine therefore has less side effects like as lethargy, sedation than clonidine. Moxonidine also has peripheral sympatholythic activity and reduces the catecholamine concentration (16).

Csete and Papp (2) showed that moxonidine not only had a hypotensive effect but also improved cerebral blood flow after intravenous administration. In this study we investigated the possible therapeutic effects of moxonidine on experimentally induced cerebral vasospasm.

\section{MATERIAL and METHODS}

Before the study was started, all necessary approvals were obtained from the Selcuk University Animals Ethics Committee (Decision No: 2008-09).

The methodology of this study is similar to our previous study (9). Experiments were carried out on 24 adult rabbits (male New Zealand albino) weighing 2500 to $3200 \mathrm{~g}$. Rabbits were randomly allocated into 3 groups as follows: Group 1: Control group $(n=8)$; group 2: SAH alone group $(n=8)$; and group 3: $\mathrm{SAH}+$ moxonidine treatment group $(n=8)$. In the control group, $2 \mathrm{~mL} C S F$ was aspirated under negative pressure, and an equal volume of saline was injected into the cisterna magna of rabbit within 2 minutes. In the SAH alone group, $2 \mathrm{~mL} C S F$ was aspirated under negative pressure, and an equal volume of fresh autologous non-heparinized blood was injected into the cisterna magna within 2 minutes. After SAH induction, the rabbits were put into the Trendelenburg position for 15 minutes for providing the freely disruption of blood into basal cisterns. The same procedure performed to the group 3 rabbits and moxonidine treatment started intraperitoneally $(0.5 \mathrm{mg} / \mathrm{kg})$ and continued once a day for 72 hours.

All animals were fasted for 12 hours before the experiment and anesthetized with a mixture of ketamine $(35 \mathrm{mg} / \mathrm{kg})$ and xylazine $(5 \mathrm{mg} / \mathrm{kg})$ administered intramuscularly. Additional doses of the anesthetic mixture were given at 20 to 30 minutes intervals, whenever deemed necessary.

The method of SAH induction was performed as follows: The dorsal parts of the head and neck were shaved. Under sterile conditions, the atlanto-occipital membrane was punctured by a 23-gauge needle positioned at an angle of 90 degrees at hyperflexion position of the head. Cerebrospinal fluid (CSF) $(2 \mathrm{~mL})$ was aspirated under negative pressure, and an equal volume of fresh autologous non-heparinised blood, which was obtained from the femoral artery, was injected slowly into the cisterna manga within two minutes. After SAH induction, rabbits were put into the Trendelenburg position for 15 minutes for providing the freely disruption of blood into basal cisterns. After confirmation of vital signs, the animals were returned to their cages. All animals breathed spontaneously throughout the procedures. Arterial blood samples were taken from each animal's catheterized ear arteries for blood gas analysis during the procedures. Only those animals with $\mathrm{PO}_{2}$ greater than $70 \mathrm{mmHg}$ and $\mathrm{PCO}_{\text {, less than }} 40 \mathrm{mmHg}$ were included in the study. Heart rate and systemic blood pressure were measured with the use of an ear artery catheter, and mean blood pressures during angiographic measurements and $\mathrm{SAH}$ induction were recorded. The physiological parameters of rabbits are summarized in Table I and Table II. Core body temperatures of the rabbits were monitored rectally and maintained at $37 \pm 0.5^{\circ} \mathrm{C}$ with a heater.

\section{Drug Treatments and Groups}

Animals were randomly allocated into three groups: group $1(n=8)$; group $2(n=8)$; and group $3(n=8)$. Intraperitoneal moxonidine treatment was started after the induction of $\mathrm{SAH}$ and administered once a day. The moxonidine (Abbott $\left.{ }^{\oplus}\right)$ dose was determined as $0.5 \mathrm{mg} / \mathrm{kg}$ according to the literature (17).

\section{Angiography}

Angiography was performed in the same fashion as our previous study (9). Digital substraction angiography was performed under anesthesia with a mixture of ketamine (35 mg/kg) and xylazine $(5 \mathrm{mg} / \mathrm{kg}$ ) that were administered intramuscularly. Additional doses of the anesthetic mixture were given at 20 to 30 minutes intervals, whenever deemed necessary.

On day 0 (baseline; before first injection of blood) and on day 3 post-SAH (immediately before death). The central ear vein was cannulated with a 16-gauge intravascular access needle (Dickinson-Bacon, UT). lomeprol (300 mg lodine/ $\mathrm{mL}$, Bracco SpA, Milan, Italy), prewarmed to $37^{\circ} \mathrm{C}$ was injected into the central ear vein at a dose of $0.3 \mathrm{~g}$ lodine $/ \mathrm{kg}$ and a rate of $2 \mathrm{~mL} / \mathrm{s}$ (70 psi). The maximum dose was 4 milliliters. After a delay of 1 second, digital subtraction angiography was performed ( 2 frames/s) in the submentovertical position and cerebral basilar artery was 5 to 7 seconds after the initial mask frame angiographic images were obtained $(9,15)$. 
Table I: Physiological Parameters of the Groups During Angiographic Measurements

\begin{tabular}{|c|c|c|c|c|c|c|c|}
\hline Group & $\mathbf{n}$ & $\mathrm{pH}$ & $\mathrm{pCO}_{2}(\mathrm{mmHg})$ & $\mathrm{pO}_{2}(\mathrm{mmHg})$ & $\mathrm{MABP}$ & $\mathrm{HR}$ \\
\hline 1 & 8 & $7.45 \pm 0.01$ & $36.3 \pm 1.2$ & $92 \pm 2.1$ & $98 \pm 1.9$ & $166 \pm 4.7$ \\
\hline 2 & 8 & $7.44 \pm 0.02$ & $35.6 \pm 1$ & $93 \pm 3.2$ & $101 \pm 2.7$ & $170 \pm 5.2$ \\
\hline 3 & 8 & $7.44 \pm 0.02$ & $34.9 \pm 1.3$ & $93 \pm 2.8$ & $100 \pm 2.9$ & $162 \pm 2.3$ \\
\hline
\end{tabular}

HR: heart rate (beats/min); MABP: mean arterial blood pressure $(\mathrm{mm} \mathrm{Hg})$.

Table II: Physiological Parameters of the Groups During the Formation of SAH

\begin{tabular}{|c|c|c|c|c|c|c|c|}
\hline Group & $\mathbf{n}$ & $\mathrm{pH}$ & $\mathrm{pCO}_{2}(\mathrm{mmHg})$ & $\mathrm{pO}_{2}(\mathrm{mmHg})$ & $\mathrm{MABP}$ & $\mathrm{HR}$ \\
\hline 1 & 8 & $7.44 \pm 0.02$ & $36.0 \pm 1.3$ & $94 \pm 2.5$ & $101 \pm 1.5$ & $172 \pm 3.9$ \\
\hline 2 & 8 & $7.45 \pm 0.01$ & $36.1 \pm 1.1$ & $93 \pm 2.7$ & $99 \pm 1.9$ & $174 \pm 4.3$ \\
\hline 3 & 8 & $7.47 \pm 0.02$ & $36.7 \pm 1.2$ & $94 \pm 3.1$ & $98 \pm 2.1$ & $166 \pm 3.2$ \\
\hline
\end{tabular}

HR: heart rate (beats/min); MABP: mean arterial blood pressure $(\mathrm{mm} \mathrm{Hg})$.

\section{Tissue Preparation}

The transcardiac perfusion-fixation method was used under general anesthesia; the thorax was opened and a cannula was placed in the aorta, through the left ventricle. The right atrial appendage was opened and the descending thoracic aorta clamped. The vascular system was perfused with 300 $\mathrm{mL}$ of heparin balanced salt solution $\left(\mathrm{pH} 7.4\right.$ at $\left.37^{\circ} \mathrm{C}\right)$ followed by $500 \mathrm{~mL}$ of $4 \%$ paraformaldehyde using a minipump. All rabbits were sacrificed after perfusion-fixation and the brain and brainstem tissue were removed. The tissues were placed in the same fixative solution and stored overnight at $4^{\circ} \mathrm{C}$. After formaldehyde fixation, the entire basilar artery was sectioned at 5 segments, $2 \mathrm{~mm}$ in length. Tissues were embedded in paraffin and hematoxylin and eosin stain was performed on $5 \mu \mathrm{m}$ cross-sections of the basilar artery.

\section{Histologic Morphometric Analysis of the Basilar Artery}

In total, 5 artery sections were analyzed per animal, so a total of 40 sections were studied for the moxonidine group and the total number of sections analyzed for the remaining group was 80. Measurements of the basilar artery luminal area, muscular wall thickness was made in a single-blind fashion by a single pathologist. Morphometric measurements on all 5 segments of basilar artery were performed by using the Image Analysis System (BAB- Bs-200 ProP Image processing and Analysis System, Turkey). The luminal area was calculated from the perimeter of the luminal border and the area contained within the boundaries of the internal elastic lamina was neglected. The luminal area for each basilar artery was obtained by averaging these measurements.

The mean \pm SD value obtained from each artery was used as the final value for a particular vessel. The wall thickness between lumen and external border of muscle layer was measured at 4 quadrants of each section of basilar artery. If an undulating luminal border was encountered, an extra measurement was taken from the internal elastic membrane to the external border of the muscle layer (9).

\section{Statistical Analysis}

Computer-assisted data analysis was performed with the help of commercially available software (SPSS version 13.0) for Windows. The Kruskal-Wallis test was used for comparison of all groups. The Post-Hoc Bonferroni test and Mann-Whitney $U$ test were used for the corrections of groups in which differences were significant. A P value less than 0.05 was accepted as significant $(p<0.05)$.

\section{RESULTS}

The average basal angiographic diameter of the basilar artery was found to be $0.72 \pm 0.05 \mathrm{~mm}$ in group $1(\mathrm{n}=8), 0.71 \pm 0.05$ $\mathrm{mm}$ in group $2(\mathrm{n}=8)$, and $0.72 \pm 0.05 \mathrm{~mm}$ in group $3(\mathrm{n}=8)$ (Figure 1A, B). The average third day angiographic diameter of the basilar artery was found to be $0.71 \pm 0.05 \mathrm{~mm}$ in group1, $0.44 \pm 0.03 \mathrm{~mm}$ in group 2 , and $0.69 \pm 0.05 \mathrm{~mm}$ in group 3 (Figure 1A, B). There was no statistically significant difference in basal angiographic luminal diameter between group 1, 2 , and $3(p>0.005)$ (Figure $2 A-C)$. Comparison of group 2 (SAH only) and group 1 to 3 showed statistically significant differences $(p<0.001)$ in third day angiographic diameter of the basilar artery (Figure 2A-C).

The average pathologic luminal area of the basilar artery was found to be $276433.73 \pm 8471.29 \mu^{2}$ in group 1, $128439.48 \pm 3489.63 \mu \mathrm{m}^{2}$ in group 2 , and $248979.63 \pm 13743.26$ $\mu^{2}$ in group 3 (Figure 3). The average basilar artery muscular layer diameter was found to be $28.291 \pm 1.38 \mu \mathrm{m}$ in group 1 , $44.714 \pm 0.99 \mathrm{~mm}$ in group 2 , and $29,374 \pm 1,73 \mu \mathrm{m}$ in group 3 (Figure $4 \mathrm{~A}-\mathrm{C}$ ). There was a statistically significant difference in pathologic luminal area of the basilar artery and muscular diameter evaluation between group 1, 2, and $3(p<0.005)$ (Figure 2A-C).

These results showed that intraperitoneal moxonidine treatment is an effective treatment modality for SAH-induced vasospasm in rabbits. The beneficial effects of moxonidine on vasospasm was observed for the first time in this study. Further studies are needed to implement this treatment strategy into the clinical practice. 

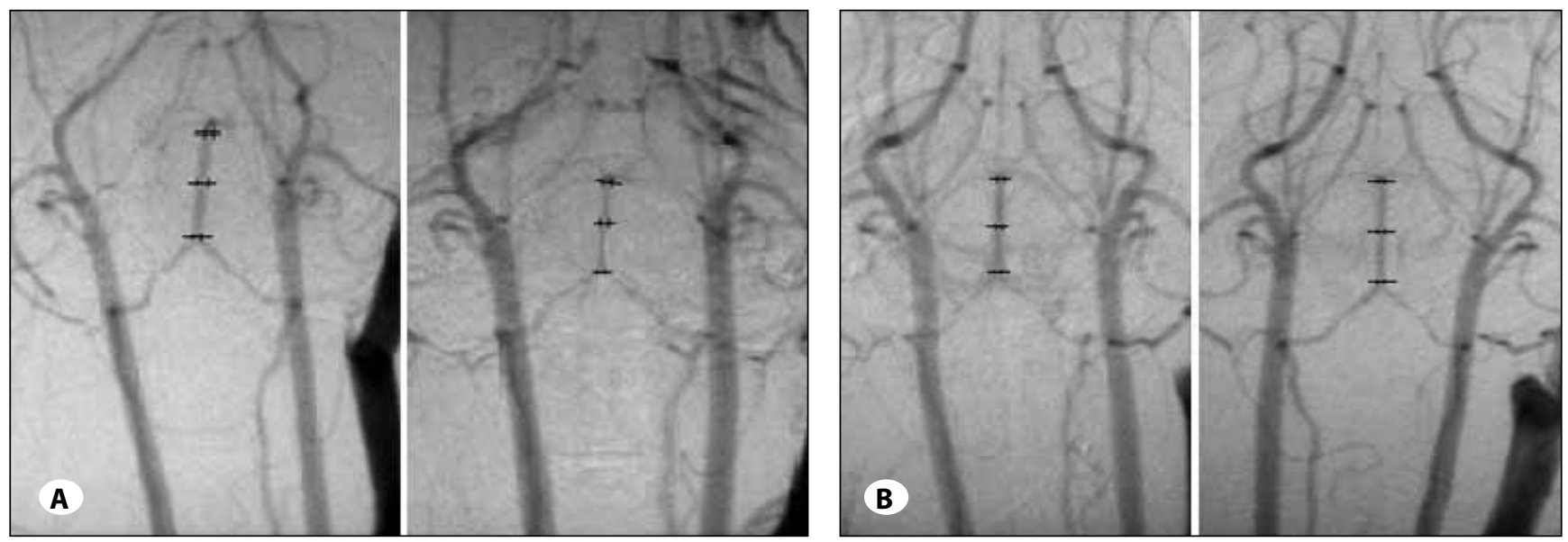

Figure 1: A) SAH alone group: Severe vasospasm of the vertebrobasilar artery can be seen. The luminal diameter of the basilar artery was measured in three segments. B) The angiographical image of the treatment group. The luminal diameter of the basilar artery was measured in 3 segments.

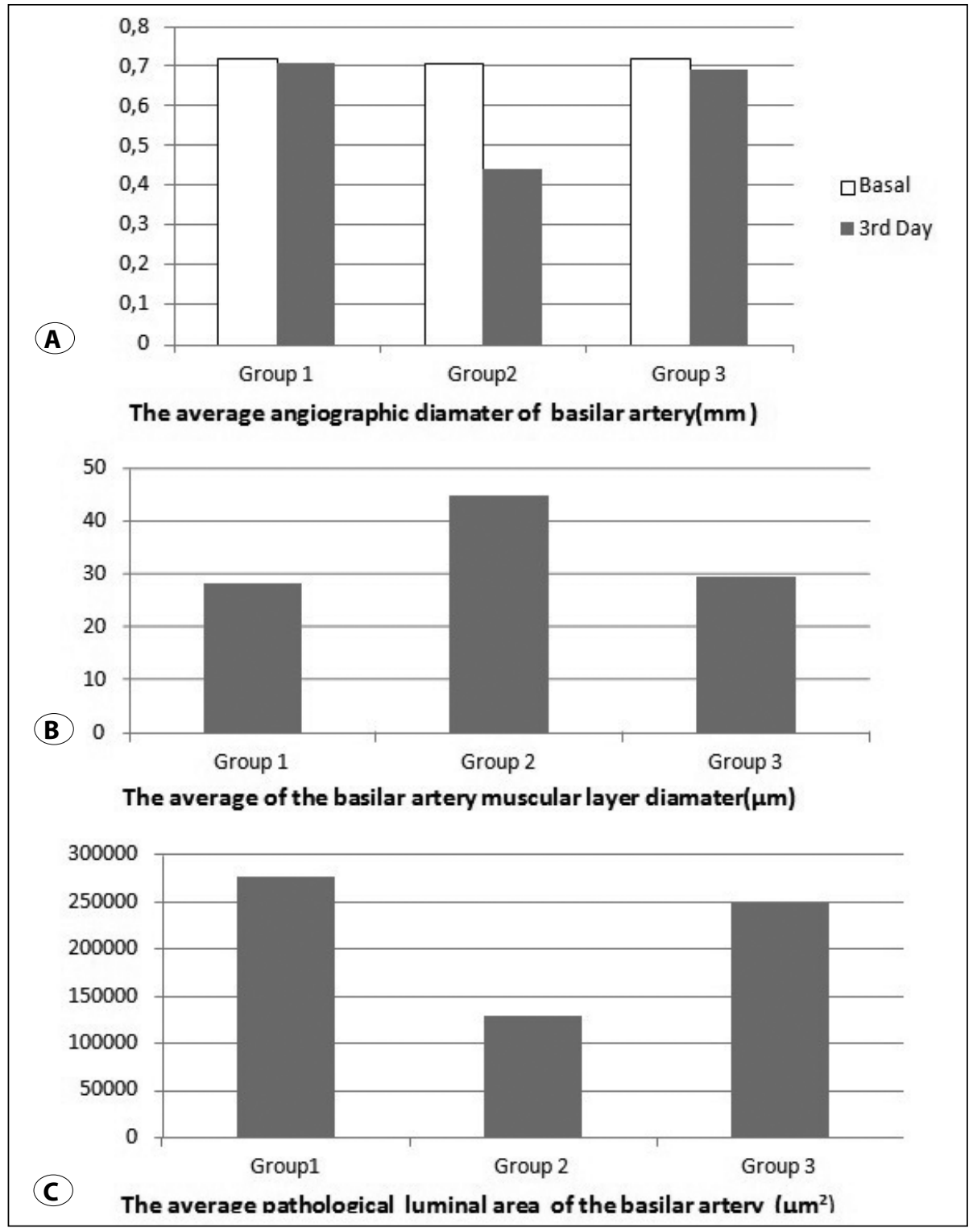

Figure 2: A) No statistically significant difference was determined in basal angiographic luminal diameter evaluation between groups ( $>0.005)$. In third day angiographic evaluation group 2 (SAH only) and group 1, 3 showed statistically significant differences $(p<0.001)$. B,C) There was a statistically significant difference in luminal area of the basilar artery and muscular thickness between groups $(p<0.005)$. [Group $1=$ Control group. Group $2=\mathrm{SAH}$ alone group. Group $3=$ $\mathrm{SAH}+$ Moxonidine group]. 


\section{DISCUSSION}

Systemic administration of moxonidine after SAH establishment resulted in a reduction in both histopathological and angiographic alterations of vasospasm in this study.
Accumulating evidence suggests that the hypotensive effect of several centrally acting antihypertensive drugs is due to their action on imidazoline receptors. This has led to the development and recent clinical use of second-generation agents such as moxonidine that possess a great selectivity

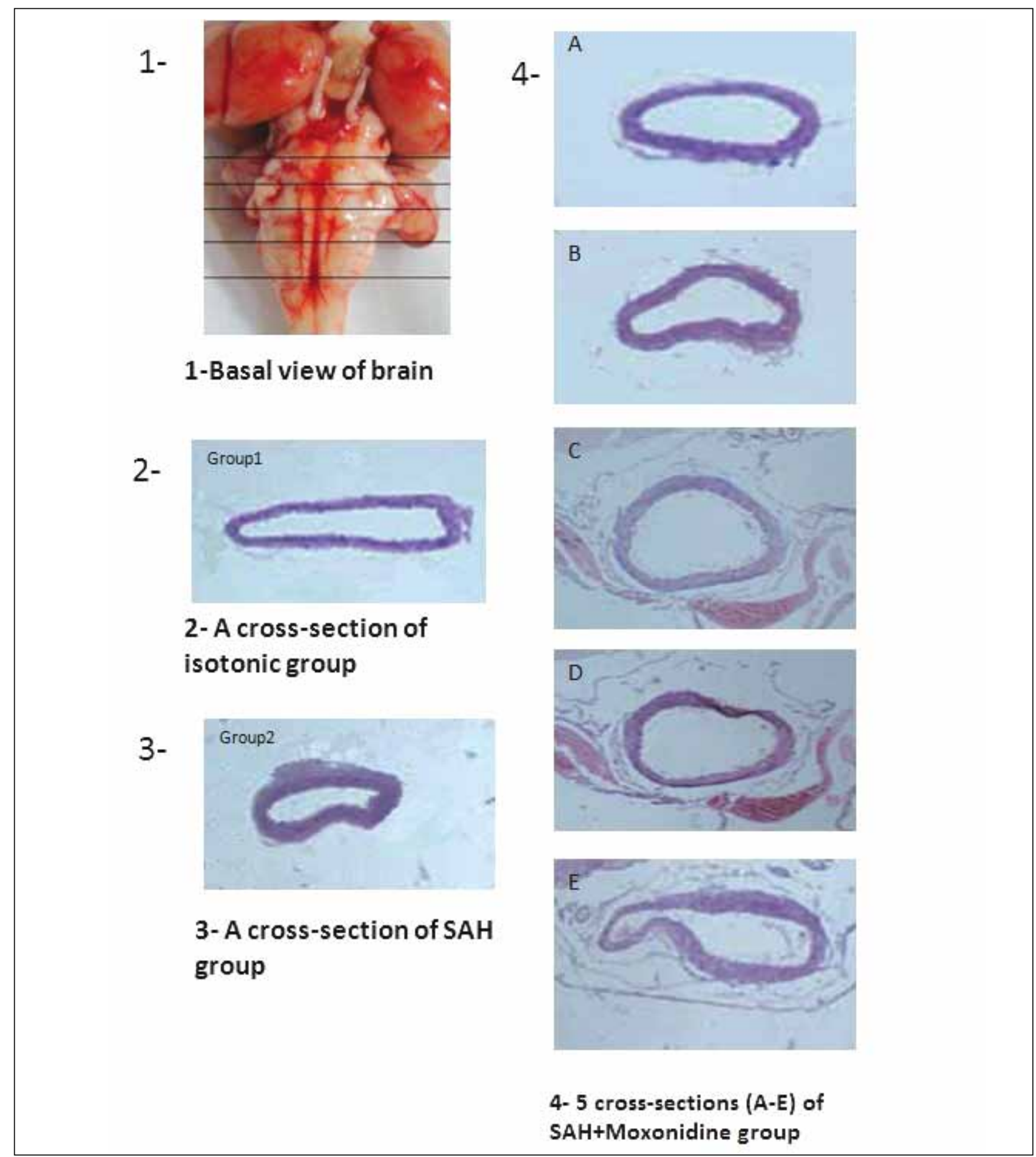

Figure 3: Illustrations of the basal view of a brain from the SAH group (left) indicating the 5 cross-section sites (A-E). [1- Basal view of brain, 2- Control Group, 3- SAH alone Group 4- SAH+Moxonidine group]. 


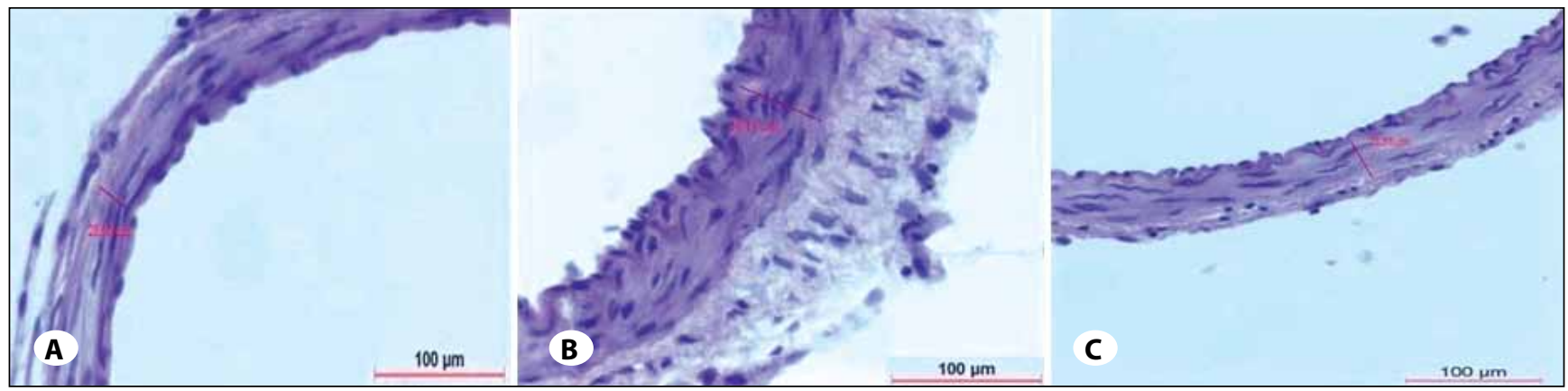

Figure 4: Histopathological photomicrograph showing basilar artery wall thickness measurements (H\&E). A measurement sites for the artery wall thickness derived from the muscular layer (inlet) is shown with lines (scale $=100 \mathrm{~mm}$ ). A) Control group. B) SAH alone group. C) $\mathrm{SAH}+$ moxonidine group.

toward these receptors (2). Previous studies showed that some of the drugs interacting with IRs may reduce the size of focal ischemic infarctions $(6,11,14)$. The mechanisms of how moxonidine protects from focal ischemia is unclear yet but direct and indirect actions should be considered. A direct action could occur via enhancement of the local intracerebral blood flow (ICBF). It has been shown that elevation of ICBF by hypercapnia or hypertension did not alter the distribution and size of the infarction produced by middle cerebral artery (MCA) occlusion (11). Another mechanism is a direct action on neurons in the salvageable zone within penumbra to protect them from cytotoxic ionic or metabolic events. A direct cytoprotective action is an unlikely mechanism, at least in cortical areas, because of the paucity of imidazoline receptors within the cortex demonstrated by binding studies (1). Imidazoline receptors are expressed in at least two major subclasses, $\mathrm{I}_{1}$ and $\mathrm{I}_{2}$. The brainstem predominantly expresses imidazoline $I_{1}$ and the cerebral cortex imidazoline $I_{2}$ receptors (2). Moxonidine may act indirectly by modifying the activity of neurons in the brainstem that project to the cortex, offering transneuronal neuroprotection. This mechanism is supported by an observation that electrical stimulation of these neuronal pathways may reduce the infarct size after MCA occlusion in rats (14). In view of these facts, the actions of moxonidine on cerebral blood flow might be indirect and be mediated by controlling the cerebral catecholamine or CAMP levels.

Several methods have been previously used to induce experimental chronic vasospasm in experimental vasospasm in various animal models (13). Two methods were commonly used on rabbits for $\mathrm{SAH}$ induction (13). The first one is the injection of fresh blood into the cisterna magna and the second one is the puncture of the basilar artery with a fine needle. We prefer the first method for its usabilty and easiness (13). The first method was modified by some authors, such as increasing the injection volume, injection of blood rich in oxyhemoglobin, repeated blood injections and open or closed access to cisterna magna, to maintain the reproducibility of the vasospasm (13). Our method's success in obtaining vasospasm was reported as $31-55 \%$ narrowing by different reports when compared with baseline basilar artery diameters $(5,7,8,10,13)$.
The small number of rabbits in this study is the main limitation of the accuracy of the results, and more studies with larger numbers are required to evaluate the efficiency of moxonidine in this group of rabbits. Another limitation is that the prior state of the basilar artery vessels also has an effect on the response to drugs. However, the heart rate, systemic blood pressure and blood gas analysis results during the procedures were recorded before and after SAH. Then mean physiological parameter values were not statistically significant between the groups.

To our knowledge, this is the first study about the beneficial effects of moxonidine on experimental cerebral vasospasm after SAH. Moxonidine prevented vasospasm successfully by increasing the arterial luminal area, reducing muscular wall thickness, and ameliorating the angiographic findings of vasospasm in this study.

Our results indicate that treatment of vasospasm with moxonidine in SAH may be promising. However, further studies with large groups and different time intervals should be done to clarify its effect on clinical vasospasm as experimental $\mathrm{SAH}$ has features that are different than clinical $\mathrm{SAH}$.

\section{REFERENCES}

1. Bricca G, Dontenwill $M$, Molines A, Feldman J, Belcourt A, Bousquet $P$ : The imidazoline preferring receptor: Binding studies in bovine, rat and human brainstem. Eur J Pharmacol 162:1-9, 1989

2. Csete K, Papp JG: Effects of moxonidine on corticocerebral blood flow under normal and ischemic conditions in conscious rabbits. J Cardiovasc Pharmacol 35: 417-421, 2000

3. Erdi MF, Guney O, Kiyici A, Esen H: The effects of alpha lipoic acid on cerebral vasospasm following experimental subarachnoid hemorrhage in the rabbit. Turk Neurosurg 21: 527-533, 2011

4. Ernsberger P, Damon TH, Graff LM, Schäfer SG, Christen MO: Moxonidine, a centrally acting antihypertensive agent, is a selective ligand for I1-imidazoline sites. J Pharmacol Exp Ther 264:172-182, 1993 
5. Flohe L, Gunzler WA, Schock HH: Glutathione peroxidase: $A$ selenoenzyme. FEBS Lett 32: 132-134, 1973

6. Gustafson I, Westerberg E, Wieloch T: Protection against ischemia-induced neuronal damage by the [alpha] ${ }_{2}^{-}$ adrenoceptor antagonist idazoxan: Influence of time of administration and possible mechanisms of action. J Cereb Blood Flow Metab 10: 885-894, 1990

7. Huang Y, Liu Y, Zhang Z: Mechanism of selenium defending against free radical damages during myocardial ischemia/ reperfusion in humans. Zhonglua Yi Xue Za Zhi 79: 731-734, 1999

8. Kirsch JR, Phelan AM, Lange DG: Reperfusion induced free radical formation following global ischemia. Pediatr Res 21 : 202-207, 1987

9. Kocaogullar Y, Ilik K, Esen H, Koc O, Guney O: Preventive effects of intraperitoneal selenium on cerebral vasospasm in experimental subarachnoid hemorrhage. J Neurosurg Anesthesiol 22: 53-58, 2010

10. Macdonald RL, Marton LS, Andrus PK, Sajdak M, Marton LS, Weir BK, Hall ED, Andrus PK: Time course of production of hydroxyl free radical after subarachnoid hemorrhage in dogs. Life Sci 75: 979-989, 2004

11. Maiese K, Pek L, Berger SB, Reis DJ: Reduction in focal cerebral ischemia by agents acting at imidazole receptors. J Cereb Blood Flow Metab 12: 53-63, 1992

12. McGirt MJ, Pradilla G, Legnani FG, Thai QA, Recinos PF, Tamargo RJ, Clatterbuck RE: Systemic administration of simvastatin after the onset of experimental subarachnoid hemorrhage attenuates cerebral vasospasm. Neurosurgery 58: 945-951, 2006
13. Megyesi JF, Vollrath B, Cook DA, Findlay JM: In vivo animal models of cerebral vasospasm: A review. Neurosurgery 46: 448-461, 2000

14. Reis DJ, Regunathan S, Golanov VE, Feinstein DL: Protection of focal ischemic infarction by rilmenidine in the animal: Evidence that interactions with central imidazoline receptors may be neuroprotective. Am J Cardiol. 74: 25-30, 1994

15. Sancak T, Silav G, Egemen N, Aldur M: Subarachnoid heamorrhage induced chronic cerebral vasospasm in the Rabbit: IV-DSA versus IA-DSA. Acta Neurochir 144:929-931, 2002

16. Sannajust F, Head GA: Involvement of imidazoline-preferring receptors in regulation of sympathetic tone. Am J Cardiol 74: 7-9, 1994

17. Wang JL, Wang L, Wu ZT, Yuan WJ, Su DF, Ni X, Yan JJ, Wang WZ: Low dose of moxonidine within the rostral ventrolateral medulla improves the baroreflex sensitivity control of sympathetic activity in hypertensive rat. Acta Pharmacol Sin 30:1594-1600, 2009

18. Webster J, Koch HF: Aspects of tolerability of centrally acting antihypertensive drugs. J Cardiovasc Pharmacol 27: 49-54, 1996

19. Zhao D, Ren LM, Lu HG, Zhang X: Potentiation by yohimbine of alpha-adrenoceptor-mediated vasoconstriction in response to clonidine in the rabbit ear vein. Eur J Pharmacol 28:201205, 2008

20. Ziegler D, Haxhiu MA, Kaan EC, Papp JG, Ernsberger P: Pharmacology of moxonidine: An I-imidazoline receptor agonist. J Cardiovasc Pharmacol 27: 26-37, 1996 